\title{
Persepsi Nasabah Terhadap Tingkat Kualitas Pelayanan Bank Syariah Cabang Malang
}

\author{
Lailatul Iffah, M. Faisal Abdullah \& Yulis Nurul Aini \\ Program Studi Ekonomi Syariah, \\ Fakultas Agama Islam, Universitas Muhammadiyah Malang \\ E-mail: lailatul@gmail.com
}

\begin{abstract}
This study aims to determine the perceptions of customers on the level of service quality of Syariah Mandiri Bank Malang branch based on five dimensions of service quality. This research used quantitative method with research subjects on BSM savings customers who used mudharabah muthlaqah contract of Syariah Mandiri Bank Malang branch. The data used in this study is the primary data through questionnaires. Questionnaires were distributed to customers as much as 53 questionnaires and sampling techniques using Purposive Sampling method. The result of the research showed that customer perception of Syariah Mandiri Bank Malang branch is very satisfied under the perception of emphaty dimension as dimension which dominates customer's perception toward service quality of the Bank.

Keywords: Customer's perception, Service Quality, Mandiri Syariah Bank.
\end{abstract}

\section{Pendahuluan}

Bank Syariah adalah bank yang beroperasi sesuai dengan prinsip-prinsip syariah Islam dan bank yang tata cara beroperasinya mengacu kepada ketentuanketentuan Al-Qur'an dan Hadist. Bank yang beroperasi sesuai prinsip syariah Islam merupakan bank yang dalam beroperasinya itu mengikuti ketentuanketentuan syariah Islam, khususnya yang menyangkut tata cara bermuamalat secara Islam. Perbankan syariah menggunakan tata cara bermuamalat tanpa mengandung unsur riba yang diisi dengan kegiata-kegiatan investasi atas dasar bagi hasil dan pembiayaan perdagangan. ${ }^{1}$

1 Karnaen Perwataamadja dan M. Syafi'i Antonio, Apa dan Bagaimana Bank Islam, (Yogyakarta: PT. Dana Bhakti Wakaf, 1997), hal. 79. 
Bank syariah sendiri mulai berkembang cukup pesat sejak tahun 2007. Awal berdirinya bank syariah yaitu Bank Muamalat Indonesia (BMI), pada tanggal 1 November 1991. Keberadaan bank syariah di tanah air mulai diakui oleh masyarakat luar dan mendapatkan pijakan yang kokoh setelah adanya UU. No. 7 tahun 1992 yang direvisi melalui UU No. 10 tahun 1998 yang dengan tegas mengakui keberanian dan fungsinya bank bagi hasil atau bank syariah serta didukung oleh fatwa MUI tentang bunga bank itu haram. ${ }^{2}$ Kebijakan pemerintah yang ikut mendorong berkembangnya layanan bank syariah membawa konsekuensi pada tingginya tingkat persaingan. ${ }^{3}$ Persaingan yang semakin meningkat dalam bisnis perbankan menuntut setiap manajemen perbankan untuk selalu memperbaiki kinerja bank agar mampu menghadapi persaingan tersebut, dengan memberikan kualitas layanan yang mampu memenuhi harapan nasabahnya. Perbankan syariah dalam memberikan layanan yang berkualitas terkadang terjadi kegagalan, hal tersebut dikarenakan adanya perbedaan atas persepsi kualitas layanan menurut nasabah dengan persepsi kualitas layanan menurut persepsi manajemen perbankan. ${ }^{4}$ Kepuasan nasabah merupakan aspek strategis dalam memenangkan persaingan dan mempertahankan citra perusahaan di masyarakat luas, sehingga kualitas pelayanan merupakan hal penting. Kualitas pelayanan menurut Pasuraman pada dasarnya adalah hasil persepsi dalam benak nasabah.

Guna mewujudkan kualitas pelayanan yang baik, insan-insan Bank Syariah Mandiri Cabang Malang perlu menyumbangkan (share) untuk BSM dengan nilainilai yang relatif seragam. Insan-insan BSM telah menggali dan menyepakati nilai-nilai dimaksud, yang kemudian disebut BSM Shared Values. ${ }^{5}$ BSM Shared Values tersebut adalah ETHIC (Excellence, Teamwork, Humanity, Integrity dan Customer Focus). Excellence meliputi upaya mencapai kesempurnaan melalui perbaikan yang terpadu dan berkesinambungan. Teamwork meliputi mengembangkan lingkungan kerja yang saling bersinergi. Humanity meliputi menjunjung tinggi nilai-nilai kemanusiaan yang religius. Integrity meliputi memahami dan menaati kode etik profesi dan berpikir serta berperilaku terpuji. Customer Focus meliputi memahami dan memenuhi kebutuhan pelanggan (eksternal dan internal) untuk menjadikan BSM sebagai mitra yang terpercaya dan menguntungan. ${ }^{6}$ Indikator yang sering dipakai dalam mengembangkan pengukuran kualitas jasa atau pelayanan, yaitu menggunakan alat ukur kualitas layanan yaitu SERVQUAL (Servivce Quality) meliputi: Tangibles, Reability, Responsiveness, Assurance, Emphaty. Skala SERVQUAL ini, berpendapat bahwa

\footnotetext{
${ }^{2}$ Muhammad, Lembaga-lembaga Keuangan Kontemporer, (Yogyakarta: UII Press. 2000), hal. 66.

3 Oktivinanto Oski, Tingkat Kepuasan Nasabah Bank Syariah Mandiri Cabang Salatiga Diukur Dari Dimensi Kualitas Pelayanan, (UIN Salatiga, Skripsi, 2012), hal.1.

4 JEAM Vol XIV September 2015, hal. 24.

${ }^{5}$ Sustainability Report, PT Bank Syariah Mandiri, 2013, hal.78.

${ }^{6}$ Ibid. 79.
} 
dalam mengevaluasi kualitas pelayanan, konsumen membandingkan antara pelayanan yang mereka harapkan dengan pelayanan yang mereka terima. ${ }^{7}$

mengenai persepsi nasabah terhadap implementasi akuntasi keuangan syariah dalam operasional perbankan berbasis syariah di Indonesia, Prasetyo menyatakan bahwa meningkatnya perbankan atau lembaga keuangan syariah di Indonesia tidak diikuti dengan bertambahnya jumlah nasabah terbukti kurang $1 \%$ umat Islam yang menjadi nasabah perbankan syariah. Fenomena yang ada disebabkan banyaknya praktik perbankan syariah yang tidak sesuai dengan syariah, sehingga menimbulkan persepsi yang menyatakan bahwa antara perbankan syariah dan perbankan konvensional itu sama saja. ${ }^{8}$ Mengenai kualitas layanan bagi nasabah di PT. Bank Syariah Mandiri Cabang Malang, Yuli menyatakan bahwa kinerja karyawan bagian teller di PT. Bank Syariah Mandiri Cabang Malang belum seluruhnya memenuhi standard. ${ }^{9}$ Fenomena tersebut menggambarkan bahwa kualitas pelayanan pada PT. Bank Syariah Mandiri masih kurang memuaskan. Perbankan berbasis syariah di Indonesia telah berjalan 20 tahun, keadaan tersebut yang membuat peneliti berupaya mengungkap fenomena di balik persepsi umat Islam Indonesia yang menyatakan bahwa antara perbankan syariah dan perbankan konvensioanal itu sama saja. ${ }^{10}$

Menurut Rachmad persepsi adalah sesuatu yang dinamis karena prinsipnya nasabah akan berpikir rasional dan mendasarkan persepsinya kepada pengalaman. Perubahan persepsi juga harus dibangun melalui pengalaman nasabah terhadap kualitas pelayanan yang diberikan oleh pihak perbankan. ${ }^{11}$ Persepsi nasabah diperoleh dari hasil yang didapatkan setelah selesai memakai layanan yang telah diberikan, baik pelayanan yang dilakukan maka pelanggan akan semakin puas, dan semakin modern layanan yang diberikan maka pelanggan akan semakin tertarik terhadap produk yang diberikan karena memberikan kenyamanan pada nasabahnya. ${ }^{12}$ Tulisan ini berupaya mengungkapkan fenomena di balik persepsi nasabah terhadap tingkat kualitas pelayanan Bank Syariah Mandiri Cabang Malang.

\section{Bank Syariah}

Bank syariah, yaitu bank yang dalam aktivitasnya, baik penghimpunan dana maupun dalam penyaluran dananya memberikan dan memakai imbalan atas dasar prinsip syariah yaitu jual beli dan bagi hasil. Bank pada dasarnya merupakan perusahaan atau lembaga perantara keuangan (financial intermediary) yaitu antara

\footnotetext{
${ }^{7}$ Jurnal Manajemen Pemasaran. Vol. 1. No. 1. April. 2006, hal. 35-43.

${ }^{8}$ Jurnal Humanity, Vol. 7, Nomor. 2, Juli. 2012: 14 - 23.

${ }^{9}$ Ibid. 83-97.

${ }^{10}$ Ibid. 14-23.

${ }^{11}$ Bisnis \& Birokrasi. Jurnal Ilmu Administrasi dan Organisasi. Vol. 15. No. 3. Sept - Des. 2008, 168-177.

${ }^{12}$ Hidayat Rachmad. Jurnal Manajemen dan Kewirausahaan. Vol. 11. No. 1. Maret 2009, hal. 59-72.
} 
pihak yang kelebihan dana dengan pihak yang kekurangan dana. Sebagai lembaga perantara bank harus menyalurkan dana yang dikumpulkan dari masyarakat tersebut kepada pihak-pihak yang membutuhkan dana dalam bentuk pinjaman atau yang lebih dikenal dengan kredit di Bank Konvensional atau pembiayaan di Bank Syariah. Pengalokasian dana dapat pula dilakukan dengan membelikan berbagai asset yang dianggap menguntungkan bank. ${ }^{13}$

Prinsip syariah adalah aturan perjanjian berdasarkan hukum Islam antara bank dan pihak lain untuk penyimpanan dana dan atau pembiayaan kegiatan usaha, atau kegiatan lainnya yang dinyatakan sesuai dengan syariah, antara lain pembiayaan berdasarkan prinsip bagi hasil (mudharabah), pembiayaan berdasarkan prinsip penyertaan modal (musyarakah), prinsip jual beli barang dengan memperoleh keuntungan (murabahah), atau pembiayaan barang modal berdasarkan prinsip sewa murni tanpa pilihan (ijarah) atau dengan adanya pilihan pemindahan kepemilikan atas barang yang disewa dari pihak bank oleh pihak lain. ${ }^{14}$

\section{Persepsi}

Persepsi (perception) adalah sebuah proses dimana individu mengatur dan menginterpretasikan kesan-kesan sensoris mereka guna memberikan arti bagi lingkungan mereka. Persepsi seseorang yang diterima pada dasarnya bisa dari realitas objektif. Sebagai contoh, sesuatu yang mungkin jika semua karyawan dalam sebuah perusahaan menganggapnya sebagai tempat kerja yang baik dengan kondisi kerja yang menyenangkan, penugasan pekerjaan yang menarik, bayaran yang bagus, tunjangan yang sangat bagus, manajemen yang pengertian dan bertanggung jawab, seperti yang diketahui oleh sebagian besar dari kita adalah sangat luar biasa untuk menemukan kecocokan yang seperti itu. ${ }^{15}$

Ma'rat menyatakan bahwa persepsi merupakan proses pengamatan seseorang yang berasal dari komponen koqnisi. Persepsi dipengaruhi oleh faktor-faktor pengalaman, proses belajar, cakrawala, dan pengetahuan. Manusia mengamati suatu objek psikologik dengan kacamatanya sendiri yang diwarnai oleh nilai diri pribadinya. Objek psikologik ini dapat berupa kejadian, ide, atau situasi tertentu. Faktor pengalaman, proses belajar, atau sosialisasi memberikan bentuk dan struktur terhadap apa yang di lihat. Pengetahuannya dan cakrawalanya memberikan arti terhadap objek psikologik tersebut. ${ }^{16}$ Di sisi lain, persepsi adalah proses yang menyangkut masuknya pesan atau informasi ke dalam otak manusia. Melalui persepsi, manusia terus menerus mengadakan hubungan dengan lingkungannya. Hubungan ini dilakukan lewat inderanya, yaitu indera penglihat, pendengar, peraba, perasa dan pencium. ${ }^{17}$ Persepsi seseorang sangat berpengaruh

\footnotetext{
13 Sigit Triandaru dan Totok Budisantoso, Bank dan Lembaga Keuangan Lain. (II, Jakarta: Salemba Empat, 2006), hal. 50

14 Wiroso, Penghimpunan Dan dan Distribusi Hasil Usaha Bank Syariah. (Jakarta: PT. Grafindo, 2005), hal. 98.

15 Timothy A. Judge, Stephen P.Robbins. Perilaku Organisasi Organizational Behavior. Penerjemah Diana Angelica, et al., (Jakarta: Salemba Empat, 2008), hal. 175.

16 Mar'at. Sikap Manusia Perubahan Serta Pengukurannya. (Jakarta: Ghalia Indonesia, 1984), hal. 22.

${ }^{17}$ Slameto, Belajar dan Faktor-Faktor yang Mempengaruhinya. (Jakarta: Rineka Cipta, 2010), hal. 16.
} 
dalam menyatakan suatu ide. Ketika menerangkan sebuah sepeda, sebelum menerangkan atau sambil menerangkannya, kita akan mempersepsikan sebuah bentuk sepeda atau rasanya naik sepeda berdasarkan pengetahuan yang pernah ditangkap, bisa berdasarkan pengalaman pribadi, atau menurut informasi orang lain, atau menurut buku yang pernah dibaca, dan sebagainya. ${ }^{18}$ Persepsi adalah suatu proses eksekusi suatu program dalam memetakan suatu realitas eksternal atau internal. Oleh karena itu, persepsi dapat dikatakan sebagai salah satu reaksi terhadap suatu realitas. Realitas dapat menjadi suatu reaksi tindakan atau prilaku sangat tergantung sugestivitas ralitas itu sendiri dan sugestivitas orang yang meresponnya. ${ }^{19}$ Persepsi adalah proses pengorganisasian, penginterpretasian terhadap rangsang yang diterima oleh organisme atau individu sehingga merupakan sesuatu yang berarti dan merupakan aktivitas yang integrated dalam diri individu. ${ }^{20}$

Selanjutnya, dengan definisi lain dinyatakan bahwa persepsi ialah daya mengenal barang, kualitas atau hubungan, dan perbedaan antara hal ini melalui proses mengamati, mengetahui, atau mengartikan setelah pancaindranya mendapat rangsang. ${ }^{21}$ Persepsi adalah proses seseorang individu memilih, mengorganisair dan menginterpretasikan masukan-masukan informasi untuk menciptakan gambaran yang memiliki arti. ${ }^{22}$ mengatur dan menginterpretasikan informasi untuk membentuk suatu yang berarti mengenai dunia. Persepsi adalah proses memperoleh atau menerima informasi dari lingkungan. Teori atau pendekatan yang menjelaskan tentang bagaimana manusia mengerti dan menilai lingkungannya. ${ }^{23}$

Persepsi Konsumen timbul ketika harapan dari pelanggan terpenuhi, dengan membandingkan kinerja yang dihasilkan sehingga pelanggan terpuaskan. Menurut Akmalia persepsi konsumen adalah proses dimana individu memilih, mengorganisasikan, serta mengartikan stimulus yang diterima melalui alat inderanya menjadi suatu makna. Faktor-faktor yang berpengaruh terhadap persepsi konsumen adalah: Harga yang rendah menimbulkan persepsi produk tidak berkualitas. Citra atau image. Tahap pelayanan, dan momen pelayanan. ${ }^{24}$

Berdasarkan pemaparan di atas, dapat disimpulkan bahwa persepsi merupakan hasil pengamatan seseorang terhadap sesuatu hal yang ada di lingkungan sekitar melalui panca indera. Persepsi diperoleh dengan cara meringkas informasi dari seseorang dan menafsirkan informasi tersebut, sehingga seseorang itu dapat memberikan tanggapan mengenai baik buruknya atau positif negatifnya informasi tersebut. Jadi persepsi pada dasarnya menyangkut hubungan antara seseorang dengan lingkungannya melalui panca indera. Seseorang menginderakan objek di

\footnotetext{
${ }^{18}$ Nugroho Nasik, Transformasi Diri (Memberdayakan diri melalui Hipnoterapi), (Jakarta: PT Gramedia Pustaka Utama, 2008), hal. 96.

${ }^{19}$ Ibid. Slameto, Belajar dan Faktor-faktor yang Mempengaruhinya, hal. 20.

${ }^{20}$ Sunaryo, Psikologi Untuk Keperawatan, Cet 1, (Jakarta: Buku Kedokteran ECG, 2004), hal. 93.

${ }^{21}$ Ibid. Sunaryo, Psikologi Untuk Keperawatan..., hal. 94.

22 Philip Kotler, Manajemen Pemasaran Analisis, Perencanaan, Implementasi dan Pengendalian. Terj. Heru Jati Purwoko Wasana, Edisi ke-5, (Jakarta: Erlangga, 1997), hal. 164.

${ }^{23}$ Laurens Marcella Joyce, Arsitektur dan Perilaku Manusia, Cet 1, (Jakarta: PT Grasindo, Februari 2004), hal.56.

${ }^{24}$ Ibid., Ikfi Akmalia, Jurnal Manajemen Bisnis, hal. 71.
} 
lingkungannya, maka kemudian memproses hasil penginderaan itu, sehingga timbullah makna tentang objek itu. ${ }^{25}$

Adapun macam-macam persepsi sebagai berikut: ${ }^{26}$ pertama, persepsi eksternal, yaitu persepsi yang terjadi karena adnya rangsang yang datang dari luar diri individu. Kedua, persepsi personal, yaitu persepsi yang terjadi karena adanya rangsang yang berasal dari dalam diri individu. Dalam hal ini yang menjadi objek adalah dirinya sendiri. Sedangkan proses terjadi persepsi adalah dengan melalui proses berikut; yaitu: ${ }^{27}$ (a) proses fisik (kealaman) -- objek $\rightarrow$ stimulus $\rightarrow$ reseptor atau alat indra. (b) proses fisiologis -- stimulus $\rightarrow$ saraf sensoris $\rightarrow$ otak. (c) proses psikologis --- Proses dalam otak sehingga individu menyadari stimulus yang diterima.

\section{Gambar 3.1: Proses Terjadinya Persepsi}

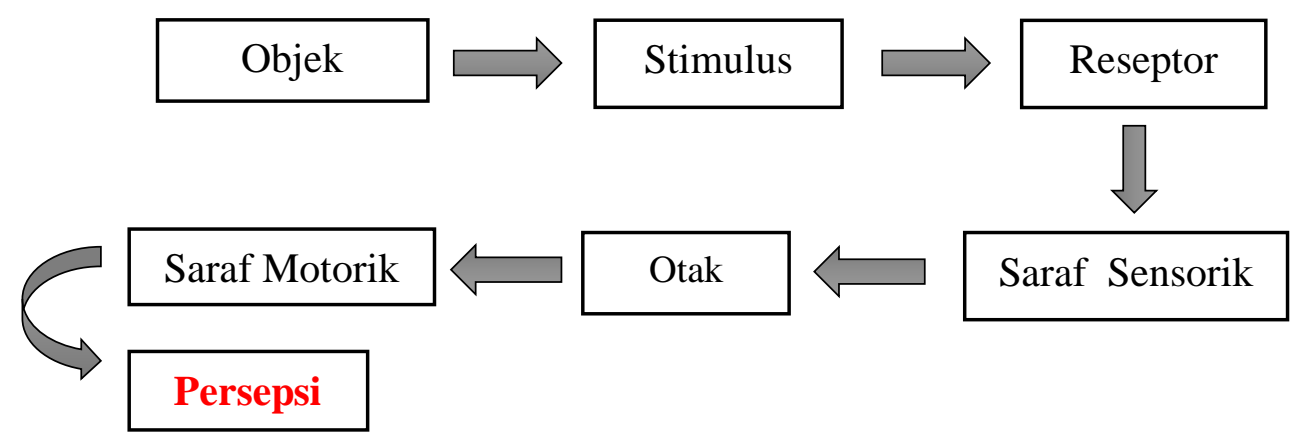

Setiap individu bisa melihat hal yang sama, namun mengartikannya secara berbeda. Sejumlah faktor beroperasi untuk membentuk dan terkadang mengubah persepsi. Faktor-faktor ini bisa terletak dalam diri pembentukan persepsi, dalam diri objek atau target yang diartikan, atau dalam konteks situasi dimana persepsi tersebut dibuat. $^{28}$ Individu melihat sebuah target dan berusaha untuk menginterpretasikan apa yang dilihat oleh alat indera, interpretasi itu sangat dipengaruhi oleh berbagai karakteristik pribadi dari pembuat persepsi individual tersebut. Karakteristik pribadi yang mempengaruhi persepsi meliputi sikap, kepribadian, motif, minat, pengalaman masa lalu, dan harapan-harapan seseorang. Sebagai contoh, apabila Anda mengharapkan para petugas polisi memiliki wewenang, orang-orang muda menjadi malas, atau para individu yang mendiami kantor umum tidak mengindahkan moral, Anda menganggap mereka seperti itu tanpa memperdulikan sifat-sifat mereka yang sebenarnya. Karakteristik target yang diobservasi bisa mempengaruhi apa yang diartikan. Individu yang bersuara keras cenderung diperhatikan dalam sebuah kelompok dibandingkan individu yang diam dengan individu yang luar biasa menarik atau tidak menarik. Target tidak dilihat secara khusus, hubungan sebuah target dengan latar belakangnya juga

\footnotetext{
${ }^{25}$ Slameto, Belajar dan Faktor-Faktor yang Mempengaruhinya...., 18.

${ }^{26}$ Sunaryo, Psikologi Untuk Keperawatan, Cet 1, 97.

${ }^{27}$ Ibid., 98.

${ }^{28}$ Ibid., Timothy A. Judge, Stephen P. Robbins, Perilaku Organisasi Organizational Behavior. 175-176.
} 
memengaruhi persepsi, seperti hal-hal yang mirip. Sebagi contoh, kaum wanita, orang-orang kulit berwarna, atau anggota dari kelompok lain yang mempunyai berbagai karakteristik yang dapat dibedakan dengan jelas menurut ciri-ciri atau warna kulit sering kali dianggap sama dalam karakteristik-karakteristik lain yang tidak terkait.

Gambar 3.2: Faktor-faktor yang Mempengaruhi Persepsi

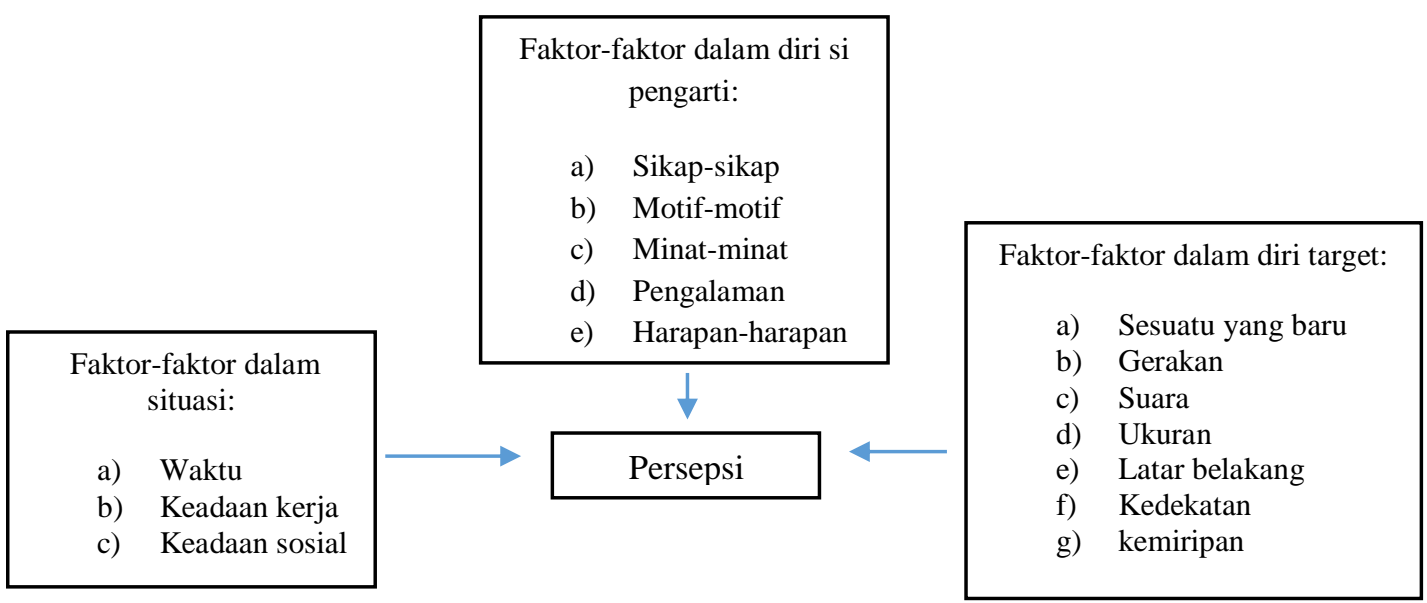

Selain faktor-faktor di atas yang mempengaruhi pengembangan persepsi seseorang, yaitu: ${ }^{29}$ (a) pendidikan/pengetahuan, (b) penghasilan/pekerjaan, (c) agama/religi.

\section{Nasabah}

Arti nasabah pada lembaga perbankan sangat penting. Nasabah ibarat nafas yang sangat berpengaruh terhadap kelanjutan suatu Bank. Bank harus dapat menarik nasabah sebanyak-banyaknya agar dana yang terkumpul dari nasabah tersebut dapat diputar oleh bank yang nantinya disalurkan kembali kepada masyarakat yang membutuhkan bantuan bank. ${ }^{30}$ Menurut Undang-Undang Perbankan Syariah No. 21 Tahun 2008, tentang Perbankan Syariah, nasabah adalah pihak yang menggunakan jasa bank syariah san atau Unit Usaha Syariah. Nasabah penyimpan adalah nasabah yang menempatkan dananya di Bank Syariah dan atau Unit Usaha Syariah dalam bentuk simpanan berdasarkan akad antara bank syariah atau Unit Usaha Syariah dan nasabah yang bersangkutan. Nasabah investor adalah nasabah yang menempatkan dananya di Bank Syariah dan atau Unit Usaha Syariah dalam bentuk investasi berdasarkan akad antara Bank Syariah dan atau Unit Usaha Syariah dan nasabah yang bersangkutan. Nasabah penerima

${ }^{29}$ Vertizal Riva'i, Kepemimpinan dan Perilaku Organisasi, Cet 1, (Jakarta: PT Raja Grafindo Persada, 2003), hal. 359.

30 Oktivinanto Oski, Tingkat Kepuasan Nasabah Bank Syariah Mandiri Cabang Salatiga Diukur Dari Dimensi Kualitas Pelayanan...., hal. 20. 
fasilitas adalah nasabah yang memperoleh fasilitas dana atau yang dipersamakan dengan itu, berdasarkan prinsip syariah. ${ }^{31}$

Nasabah adalah orang yang berinteraksi dengan bank dan mereka adalah pengguna produk yang secara kontinu dan berulang-ulang datang ke bank untuk memuaskan keiinginannya dengan memiliki suatu produk atau mendapatkan suatu jasa dan membayar produk atau jasa tersebut. ${ }^{32}$ Berdasarkan beberapa pendapat diatas maka penulis menarik kesimpulkan bahwa nasabah merupakan orang yang memiliki peranan penting dalam kelanjutan perkembangan bank, nasabah bank meliputi pengguna produk atau jasa.

Salah satu tujuan utama perusahaan khususnya perusahaan jasa (dalam hal ini adalah bank) adalah menciptakan kepuasan pelanggan. Kepuasan pelanggan sebagai hasil penilaian pelanggan atau nasabah terhadap apa yang diharapkannya dengan membeli dan mengkonsumsi suatu produk atau jasa. Harapan tersebut dibandingkan dengan kinerja yang diterimanya dengan mengkonsumsi produk atau jasa tersebut, apabila keinginan yang diterimahnya lebih besar daripada harapannya, maka pelanggan puas, sebaliknya kinerja yang diberikan dari pemakaian produk atau jasa tersebut lebih kecil daripada apa yang diharapkannya maka pelanggan tidak puas. ${ }^{33}$

\section{Kualitas Pelayanan}

Pelayanan adalah suatu bentuk layanan yang diselenggarakan oleh penyedia jasa kepada pengguna layanan tersebut. Layanan dapat berupa barang yang dihasilkan dari suatu proses produksi atau dapat pula berupa pelayanan yang ditawarkan. Kualitas pelayanan dapat diukur dengan cara membandingkan antara apa yang diharapkan oleh pengguna layanan dan apa yang diterima oleh pengguna layanan. Kualitas pelayanan (sevice quality) di bangun atas adanya perbandingan antara dua faktor utama yaitu persepsi pelanggan atas pelayanan yang nyata mereka terima (perceived service) dengan pelayanan yang sesungguhnya diharapkan atau diinginkan (expected service). Dengan kata lain, kualitas pelayanan adalah seberapa jauh perbedaan antara kenyataan dan harapan pelanggan atas pelayanan yang mereka terima atau peroleh. kualitas pelayanan bank adalah tingkat keunggulan yang diharapkan nasabah dan pengendalian atas tingkat keunggulan tersebut untuk memenuhi keinginan nasabah, dengan kata lain ada dua faktor utama yang mempengaruhi kualitas pelayanan bank yaitu harapan nasabah (expectation) dan kinerja bank yang dirasakan nasabah (performance).

Kualitas pelayanan bank merupakan kinerja aktual bank yang diberikan kepada nasabahnya. Berdasarkan konsep servqual kualitas pelayanan bank pada dasarnya adalah hasil persepsi dalam benak nasabah. Perceived servive quality ini

\footnotetext{
${ }^{31}$ Ibid., Oktivinanto Oski, Tingkat Kepuasan Nasabah Bank Syariah Mandiri Cabang Salatiga Diukur Dari Dimensi Kualitas Pelayanan...., hal. 21.

${ }^{32}$ Astuti Tri, "Pengaruh Persepsi Nasabah Tentang Tingkat Suku Bunga, Promosi dan Kualitas Pelayanan Terhadap Minat Menabung Nasabah”, UIN Sunan Kalijaga Yogyakarta, (Skripsi), 2013, hal.14.

${ }^{33}$ M, Nur Rianto Al Arif, Dasar-Dasar Pemasaran Bank Syariah, (Bandung: Alfabeta, 2010), hal. 193.
} 
terbentuk dalam bentuk nasabah setelah membandingkan antara kinerja pelayanan bank yang mereka terima dengan yang mereka harapkan (SERVQUAL - service performance - service expectation).

Perbandingan antara persepsi dan harapan bisa memunculkan tiga kemungkinan, yaitu; (a) persepsi lebih besar daripada harapan nasabah -yang berarti nasabah merasa sangat puas dengan kualitas pelayanan yang diberikan bank. (b) persepsi lebih kecil daripada harapan nasabah -yang berarti harapan nasabah terhadap kualitas pelayanan bank tidak tercapai. (c) persepsi sama dengan harapan nasabah terhadap kualitas jasa pelayanan bank, dengan arti nasbah puas dengan pelayanan yang ada.

Kualitas pelayanan yaitu memberikan kesempurnaan pelayanan yang dilakukan oleh penyedia layanan dalam memenuhi kebutuhan dan keinginan pelanggan serta ketepatan penyampaiannya untuk mengimbangi harapan pelanggan. Kualitas pelayanan menjadi hal penting yang harus diperhatikan serta dimaksimalkan agar mampu bertahan dan tetap dijadikan pilihan oleh pelanggan.

Pelayanan menjadi salah satu faktor yang membangun secara langsung dengan para nasabah, baik pelayanan dalam bentuk kehandalan, ketanggapan, keyakinan, kepedulian ataupun pelayanan yang berwujud yang mencangkup hal sarana dan pra sarana yang dimiliki. Pelayanan yang dikemukakan Tjiptono adalah segala sesuatu yang dilakukan pihak tertentu (individu maupun kelompok ) kepada pihak lain (individu maupun kelompok). Faktor pendukung yang mempengaruhi kualitas pelayanan yang baik. Pertama adalah faktor manusia yang memberikan pelaynan tersebut. Kedua adalah faktor tersedianya sarana dan prasarana yang mendukung kecepatan, ketepatan, dan keakuratan pekerjaan. Kualitas pelayanan memainkan peranan penting dalam membantu perusahaan membangun hubungan dengan pelanggan. Pelanggan kualitas pelayanan adalah menyesuaikan diri dengan spesifikasi yang dituntut pelanggan.

Terdapat beberapa faktor yang dapat menyebabkan kualitas pelayanan menjadi buruk, antara lain;

a) Tidak terampil dalam melayani konsumen

b) Cara berpakaian tidak sesuai

c) Tutur katanya kurang sopan atau bahkan menyebalkan

d) Bau badan mengganggu

e) Selalu cemberut atau pasang tampang angker.

Adapun faktor-faktor yang perlu diperhatikan dalam meningkatkan kualitas pelayanan adalah: (1) mengidentifikasi determinan utama kualitas pelayanan. Langkah pertama yang harus dilakukan adalah melakukan riset untuk mengidentifikasi determinan kualitas pelayanan yang penting bagi pasar sasaran dan memperkirakan penilaian yang diberikan pasar sasaran. (2) mengelola harapan pelanggan atau nasabah. Banyak janji yang diberikan, maka semakin besar pula harapan pelanggan yang pada gilirannya akan menambah peluang tidak dapat terpenuhinya harapan pelanggan oleh perusahaan, untuk itu ada satu hal yang dapat dijadikan pedoman yaitu jangan janjikan apa yang tidak bisa diberikan tetapi berikan lebih dari yang dijanjikan. (3) mengelola bukti, pengelolaan bukti kualitas pelayanan bertujuan untuk memperkuat persepsi pelanggan selama dan sesudah pelayanan diberikan, oleh karena itu pelanggan lebih cenderung memperhatikan fakta-fakta tangible. (4) mengembangkan kualitas budaya. Kualitas budaya merupakan sistem organisasi yang menghasilkan lingkungan 
yang kondusif bagi pembentukan dan penyempurnaan kulaitas secara terus menerus. Budaya kualitas terdiri dari filosofi, keyakinan, sikap, norma, nilai, tradisi, prosedur dan harapan.

Adapun dimensi kualitas jasa layanan SERVQUAL merupakan dimensi kualitas jasa dimana setiap jasa yang ditawarkan memiliki beberapa aspek yang dapat dipergunakan untuk mengetahui tingkat kualitasnya. Terdapat lima dimensi pelayanan berkualitas, antara lain:

1) Bukti langsung (tangibles)

Definisi bukti langsung yaitu kemampuan suatu perusahaan dalam menunjukkan eksistensi kepada pihak eksternal. penampilan dan kemmpuan sarana dan prasarana, fisik perusahaan dan keadaan lingkungan sekitarnya adalah bukti nyata dari pelayanan yang di berikan oleh pemberi jasa, yang meliputi fasilitas fisik (gedung, gudang, dan lain sebagainya). Perlengkapan dan peralatan yang dipergunakan (teknologi), serta penampilan pegawainya.

2) Kehandalan (reliability)

Kehandalan adalah kemampuan perusahaan untuk memberikan pelayanan sesuai yang dijanjikan secara akurat dan terpercaya. Kinerja harus sesuai dengan harapan nasabah yang berarti ketepatan waktu, pelayanan yang sama, untuk semua nasabah tanpa kesalahan, sikap yang simpatik, dan dengan akurasi yang tinggi.

3) Daya tanggap (responsiveness)

Daya tanggap adalah suatu kemampuan untuk membantu dan memberikan pelayanan yang cepat (responsif) dan tepat kepada nasabah, dengan penyampaian informasi yang jelas. Menghiraukan konsumen menunggu tanpa adanya suatu alasan yang jelas menyebabkan persepsi yang negative dalam kualitas pelayanan.

4) Jaminan (assurance)

Definisi jaminan yaitu pengetahuan, kesopanan, dan kemampuan para pegawai perusahaan untuk menumbuhkan rasa percaya para nasabah kepada perusahaan. Terdiri dari beberapa komponen antara lain: komunikasi, kredibilitas, keamanan, kompetensi, dan sopan santun.

5) Empati (emphaty)

Empati adalah memberikan perhatian yang tulus dan bersifat individual atau pribadi, yang diberikan kepada para nasabah dengan berupaya memahami keinginan nasabah. Dimana suatu perusahaan diharapkan memiliki pengertian dan pengetahuan tentang nasabah, memahami kebutuhan nasabah secara spesifik, serta memiliki waktu pengoperasian yang nyaman bagi nasabah.

\section{Analisis dan Pembahasan}

Berdasarkan analisis dan pembahasan yang telah diuraikan pada bab-bab sebelumnya dan juga berdasarkan pada hasil penelitian yang telah dibahas pada bab empat dengan bantuan regresi sederhana dan hasil wawancara dengan pihak bank.

\subsection{Uji Validitas dan Reabilitas}

Pengujian Validitas dan Reabilitas instrumen kuesioner dilakukan dengan bantuan perangkat lunak SPSS V.23. Berikut ini adalah hasil pengujian Validitas dan Reabilitas: 
Tabel 6.1: Hasil Uji Reliabilitas

\begin{tabular}{|r|r|r|}
\hline \multicolumn{3}{|c|}{ Reliability Statistics } \\
\begin{tabular}{|r|r|} 
Cronbach's \\
Alpha
\end{tabular} & $\begin{array}{c}\text { Cronbach's } \\
\text { Alpha Based on } \\
\text { Standardized } \\
\text { Items }\end{array}$ & N of Items \\
\hline, 726 &, 853 & 16 \\
\hline
\end{tabular}

Berdasarkan hasil pengujian Reabilitas diatas dapat disimpulkan bahwa instrumen kuesioner reliable atau valid. Cronbach's Alpha yang diperoleh adalah 0,726 diatas Cronbach's Alpha yang disarankan 0,6.

Tabel 6.2 Hasil Uji Validitas

\begin{tabular}{|l|r|r|r|r|}
\hline \multicolumn{5}{|c|}{ Item-Total Statistics } \\
& $\begin{array}{c}\text { Scale Mean if } \\
\text { Item Deleted }\end{array}$ & $\begin{array}{c}\text { Scale Variance } \\
\text { if Item Deleted }\end{array}$ & $\begin{array}{c}\text { Cronbach's } \\
\text { Total Correlation }\end{array}$ & $\begin{array}{c}\text { Alpha if Item } \\
\text { Deleted }\end{array}$ \\
\hline X1 & 134,38 & 75,739 &, 422 &, 714 \\
X2 & 134,96 & 71,383 &, 495 &, 701 \\
X3 & 134,38 & 73,509 &, 672 &, 703 \\
X1 & 134,17 & 78,374 &, 315 &, 723 \\
X2 & 135,11 & 68,872 &, 562 &, 692 \\
X3 & 134,55 & 74,329 &, 427 &, 710 \\
X1 & 134,40 & 73,705 &, 640 &, 705 \\
X2 & 134,28 & 73,976 &, 689 &, 705 \\
X3 & 134,85 & 76,361 &, 191 &, 723 \\
X1 & 134,21 & 77,552 &, 404 &, 720 \\
X2 & 134,34 & 77,190 &, 274 &, 721 \\
X3 & 134,28 & 75,822 &, 575 &, 713 \\
X1 & 134,40 & 75,128 &, 449 &, 712 \\
X2 & 134,36 & 75,657 &, 477 &, 713 \\
X3 & 134,21 & 77,014 &, 502 &, 718 \\
TOT_SKOR & 69,55 & 19,983 & 1,000 &, 774 \\
\hline
\end{tabular}

Tabel 6.3 Ringkasan Pengujian Validitas Instrumen

\begin{tabular}{|l|r|l|l|}
\hline & $r_{\text {hitung }}$ & $r_{\text {tabel }}$ & Pernyataan \\
\hline$X 1$ &, 422 & 0,2241 & VALID \\
\hline$X 2$ &, 495 & 0,2241 & VALID \\
\hline X3 &, 672 & 0,2241 & VALID \\
\hline X1 &, 315 & 0,2241 & VALID \\
\hline X2 &, 562 & 0,2241 & VALID \\
\hline X3 &, 427 & 0,2241 & VALID \\
\hline
\end{tabular}




\begin{tabular}{|l|l|l|l|}
\hline X1 &, 640 & 0,2241 & VALID \\
\hline X2 &, 689 & 0,2241 & VALID \\
\hline X3 &, 191 & 0,2241 & VALID \\
\hline X1 &, 404 & 0,2241 & VALID \\
\hline X2 &, 274 & 0,2241 & VALID \\
\hline X3 &, 575 & 0,2241 & VALID \\
\hline X1 &, 449 & 0,2241 & VALID \\
\hline X2 &, 477 & 0,2241 & VALID \\
\hline X3 &, 502 & 0,2241 & VALID \\
\hline
\end{tabular}

Sumber: Data Primer diolah 2017

Dengan tingkat signifikansi 10\% dapat diperoleh nilai r-tabel sebesar 0,224. Pengukuran Validitas adalah apabila r-hitung positif lebih besar dari r-tabel maka butir pertanyaan dinyatakan Valid. Dari tabel diatas dapat disimpulkan bahwa semua butir pertanyaan adalah Valid.

\subsection{Gambaran Umum Responden}

Untuk mendapatkan gambaran umum mengenai responden sebagai obyek dari penelitian ini, maka dipergunakan kuesioner sebagai alat memperoleh data. Hasil penelitian yang telah dilakukan dengan jumlah responden sebesar 53 responden yaitu nasabah yang melakukan transaksi dengan akad mudharabah muthlaqah di Bank Syariah Mandiri Cabang Malang. Diperoleh karakteristik responden yang meliputi jenis kelamin, usia, pekerjaan, pendapatan, informasi mengenai adanya bank, jumlah dalam menggunakan jasa bank, dan jasa bank yang digunakan. Masing-masing karakteristik responden dapat dilihat dari penjelasan berikut ini:

\section{a. Jenis Kelamin}

Berdasarkan jenis kelamin responden dapat dijelaskan melalui tabel berikut ini.

Tabel 6.4 Karakteristik Responden Menurut Jenis Kelamin

\begin{tabular}{|c|c|c|c|}
\hline No & Jenis Kelamin & Responden & Prosentase (\%) \\
\hline 1 & Laki - laki & 29 & 54,71698113 \\
\hline 2 & Perempuan & 24 & 45,28301887 \\
\hline \multicolumn{2}{|c|}{ Jumlah } & 53 & 100 \\
\hline
\end{tabular}

Sumber: Data Primer diolah 2017

Gambaran yang terlihat pada Tabel 4.1 di atas menunjukkan bahwa dari 53 responden (nasabah) berjenis laki-laki yang lebih banyak menjadi nasabah Bank Syariah Mandiri Cabang Malang dengan prosentase sebesar 54,71\%. Responden berjenis perempuan lebih sedikit jumlahnya yaitu dengan prosentase sebesar $45,28 \%$. 


\section{b. Usia responden}

Usia nasabah Bank di Malang ternyata sangat bervariasi, data tersebut dapat dilihat pada tabel berikut:

\section{Tabel 6.5 Karakteristik Responden Menurut Usia}

\begin{tabular}{|c|c|c|c|}
\hline No & Usia & Responden & Prosentase (\%) \\
\hline 1 & 18-28 Tahun & 11 & 20,75471698 \\
\hline 2 & 29-39 Tahun & 18 & 33,96226415 \\
\hline 3 & 40-49 Tahun & 13 & 24,52830189 \\
\hline 4 & $>50$ Tahun & 11 & 20,75471698 \\
\hline \multicolumn{2}{|c|}{ Jumlah } & 53 & 100 \\
\hline
\end{tabular}

Sumber: Data Primer diolah 2017

Berdasarkan Tabel 6.2 dapat diketahui bahwa dari 53 responden (Nasabah) PT. Bank Syariah Mandiri Cabang Malang terdapat (20,75\%) yang berusia 18-20 tahun, sebanyak $(33,96 \%)$ yang berusia $29-39$ tahun, sebanyak $(24,52 \%)$ yang berusia $40-49$ tahun, dan terdapat $(20,75 \%)$ yang berusia 50 tahun keatas. Hasil tersebut, menunjukkan bahwa prosentase terbesar atau jumlah responden terbanyak terdapat pada responden berusia 29-39 tahun sebesar $(33,96 \%)$.

\section{c. Pendidikan Terakhir Responden}

Berikut ini adalah tabel tentang pendidikan terakhir responden:

Tabel 6.6 Karakteristik Responden Menurut Pendidikan Terakhir

\begin{tabular}{|c|c|c|c|}
\hline No & Tingkat Pendidikan & Responden & Prosentase (\%) \\
\hline 1 & SMA & 28 & 52,83018868 \\
\hline 2 & Diploma & 2 & 3,773584906 \\
\hline 3 & S1 & 16 & 30,18867925 \\
\hline 4 & S2 & 1 & 1,886792453 \\
\hline 5 & S3 & 0 & 0 \\
\hline 6 & Lain-lain & 6 & 11,32075472 \\
\hline & Jumlah & 53 & 100 \\
\hline
\end{tabular}

Sumber: Data Primer diolah 2017

Berdasarkan Tabel 6.3 dapat diketahui bahwa dari 53 responden (Nasabah) PT. Bank Syariah Mandiri Cabang Malang yang berpendidikan SMA sebanyak $(52,83 \%)$, Diploma berjumlah sebanyak $(3,77 \%)$, S1 berjumlah sebanyak 
(30,18\%), S2 berjumlah sebanyak $(1,88 \%)$, S3 tidak ada dan untuk kategori lainlain (SD atau SMP) berjumlah (11,32\%). Hasil tersebut, menunjukkan bahwa prosentase terbesar atau jumlah responden terbanyak terdapat pada responden berpendidikan terakhir SMA sebesar $(52,83 \%)$.

\section{d. Pekerjaan Repsonden}

Tabel 6.7 Karakteristik Responden Menurut Tingkat Pekerjaan

\begin{tabular}{|c|c|c|c|}
\hline No & Pekerjaan & Responden & Prosentase (\%) \\
\hline 1 & Pelajar atau mahasiswa & 7 & 13,20754717 \\
\hline 2 & PNS & 6 & 11,32075472 \\
\hline 3 & Pegawai Swasta & 9 & 16,98113208 \\
\hline 4 & Wiraswasta & 23 & 43,39622642 \\
\hline 5 & Lain-lain & 8 & 15,09433962 \\
\hline & Jumlah & 53 & 100 \\
\hline
\end{tabular}

Sumber: Data Primer diolah 2017

Dari hasil Tabel 6.4 dapat diketahui bahwa jenis pekerjaan nasabah PT. Bank Syariah Mandiri Cabang Malang yang terbanyak adalah wiraswasta dengan prosentase sebesar (43,39\%). Jenis pekerjaan nasabah Bank Syariah Mandiri Cabang Malang yang paling sedikit adalah PNS yaitu dengan prosentase $(11,32 \%)$.

\section{e. Tingkat Pendapatan Responden}

Berikut ini adalah tabel tentang tingkat pendapatan responden:

Tabel 6.8 Karakteristik Responden Menurut Tingkat Pendapatan

\begin{tabular}{|c|c|c|c|}
\hline No & Pendapatan & Responden & Prosentase (\%) \\
\hline 1 & $<$ Rp 2000.000 & 18 & 33,96226415 \\
\hline 2 & Rp. 2000.000- Rp 4000.000 & 28 & 52,83018868 \\
\hline 3 & $>$ Rp. 4000.000 & 7 & 13,20754717 \\
\hline \multicolumn{2}{r|}{ Jumlah } & 53 & 100 \\
\hline
\end{tabular}

Sumber: Data Primer diolah 2017

Berdasarkan Tabel 4.5 dapat diketahui bahwa dari 53 responden (Nasabah) PT. Bank Syariah Mandiri Cabang Malang yang perbendapatan < Rp 2.000.000 sebanyak (33,96\%), Rp 2.000.000 - 4.000.000 sebanyak (52,83\%) dan pendapatan diatas Rp 4.000.000 sebanyak (13,20\%). Hasil tersebut, menunjukkan 
bahwa prosentase terbesar atau jumlah pendapatan nasabah terbanyak terdapat pada responden yang berpendapatan Rp 2.000.000 - 4.000.000 yaitu sebanyak (52,83\%). Tingkat pendapatan nasabah Bank Syariah Mandiri Cabang Malang yang paling sedikit adalah > Rp 4.000.000 yaitu sebanyak $(13,20 \%)$.

\section{f. Sudah Berapa kali Menggunakan Jasa Pelayanan PT. Bank Syariah Mandiri Cabang Malang}

Tabel 6.9. Distribusi Responden berdasarkan Berapa kali Menggunakan Jasa Bank

\begin{tabular}{|c|c|c|c|}
\hline No & Jumlah Penggunakan Jasa & Total & Prosentase $(\%)$ \\
\hline 1 & $<3$ kali & 21 & 39,62264151 \\
\hline 2 & $3-6$ kali & 12 & 22,64150943 \\
\hline 3 & $>6$ kali & 20 & 37,73584906 \\
\hline & Jumlah & 53 & 100 \\
\hline
\end{tabular}

Sumber: Data Primer diolah 2017

Berdasarkan Tabel 4.6 menunjukkan bahwa distribusi responden berdasarkan berapa kali menggunakan jasa pelayanan Bank Syariah Mandiri Cabang Malang setiap bulannya. Dari data 53 responden menunjukkan bahwa jumlah < 3 kali sebanyak (39,62\%), 3-6 kali sebanyak (22,64\%), > 6 kali sebanyak (37\%). Hasil tersebut, menunjukkan bahwa prosentase terbesar atau jumlah penggunaan jasa pelayanan terbanyak terdapat pada $<3$ kali setiap bulannya yaitu sebesar $(39,62)$. Penggunaan jasa pelayanan Bank Syariah Mandiri Cabang Malang yang paling sedikit adalah 3-6 kali yaitu sebesar (22,64\%).

\section{g. Persepsi Nasabah terhadap Pelayanan}

\section{Grafik 6.10. Hasil Persepsi Nasabah Terhadap Kualitas Pelayanan PT Bank Syariah Mandiri Cabang Malang}




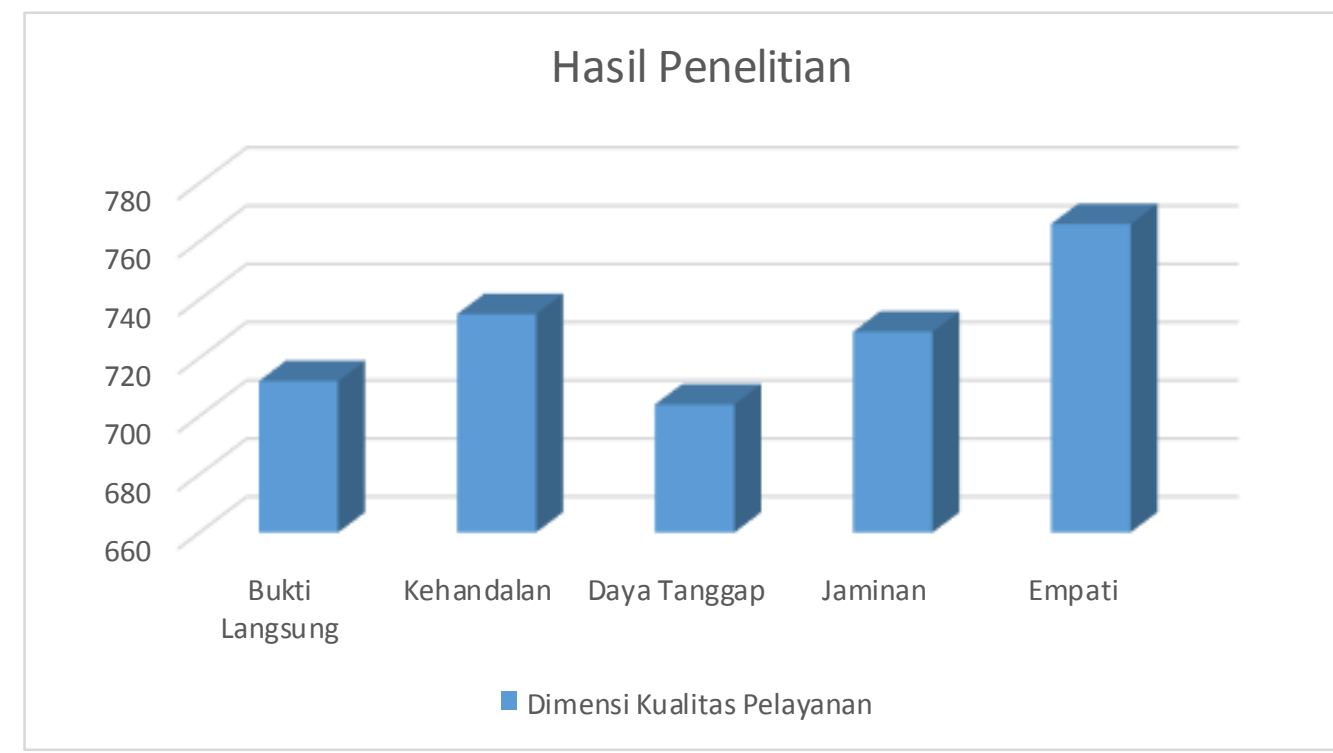

Sumber : Data Primer diolah 2017

Berdasarkan gambar 4.3 dapat disimpulkan bahwa persepsi nasabah terhadap kualitas pelayanan Bank Syariah Mandiri Cabang Malang sangat puas terhadap pelayanan yang diterima dari pegawai bank. Dilihat dari empati nasabah yang menempati nilai tertinggi dibanding kehandalan, jaminan, daya tanggap, dan bukti langsung. Sehingga empati sangat mempengaruhi persepsi nasabah terhadap kualitas pelayanan Bank Syariah Mandiri Cabang Malang.

\section{Kesimpulan}

Berdasarkan hasil penelitian dan pembahasan yang telah dilakukan dapat ditarik kesimpulan bahwa secara umum Bank Syariah Mandiri Cabang Malang sudah menjalankan kinerja operasionalnya dengan sangat baik. Hal ini terbukti pada banyaknya nasabah yang memiliki persepsi mengenai kualitas pelayanan bank pada kategori sangat puas. Namun kategori tersebut belum sepenuhnya dapat memenuhi harapan nasabah karena masih ada kinerja pelayanan yang masih kurang memuaskan nasabah. Hal ini dikarenakan masih ada sebagian penilaian negatif dari nasabah pada penggunaan peralatan dan teknologi dalam operasional Bank Syariah Mandiri bahwa kinerjanya masih kurang optimal, sehingga menyebabkan nasabah terlalu lama mengantri karena lamanya proses pelayanan. Dimensi jaminan memiliki pengaruh persepsi yang sangat besar, namun pada poin ketiga sistem bagi hasil menyatakan cukup puas.

Kualitas pelayanan merupakan faktor utama dalam menentukan persepsi nasabah dan hendaknya menjadi perhatian utama demi keberlangsungan suatu usaha penyedia jasa. Dengan pelayanan yang yang berkualitas, maka nasabah akan merasa puas sehingga persepsi nasabah akan baik pula dalam menilai pelayanan bank. 


\section{Daftar Pustaka}

Akmalia Ikfi. 2012. April. Jurnal Manajemen Bisnis. Vol 2. No 01.

Astuti Tri. 2013. Pengaruh Persepsi Nasabah Tentang Tingkat Suku Bunga, Promosi dan Kualitas Pelayanan Terhadap Minat Menabung Nasabah. Yogyakarta.

Alghifari. 2010. Mengukur Kualitas Layanan. Yogyakarta: Kurnia Kalam Semesta.

Aristiana Ita Melina. 2010. Pengaruh Kualitas Pelayanan Terhadap Kepuasan

Nasabah Dan Tingkat Laba Pada PD. BPR-BKK. Jepara. Alghifari. 2015. Mengukur Kualitas Layanan. STIE YKPN. Yogyakarta.

Arifin Johar. 2008. Statistik Bisnis Terapan dengan Microsoft Excel 2007. Jakarta: PT Gramedia.

Azwar Saifuddin.1999. Metode Penelitian. Cet 2. Yogyakarta: Pustaka Belajar (Anggota IKAPI).

Bisnis \& Birokrasi. 2008. Sept-Des. Jurnal Ilmu Administrasi dan Organisasi.

Vol. 15. No. 3.

Dian Ariani. 2007. Persepsi Masyarakat Umum Terhadap Bank Syariah di Medan. Medan: USU.

E. Bahruddin \& Asep Saepul Hamidi. 2014. Metode Penelitian Kuantitatif Aplikasi Dalam Pendidikan. Ed 1. Cet 1. Yogyakarta : Deepublish. Fandy, Tjiptono. 2008. Service Mangement Mewujudkan Layanan Prima.

Yogyakarta : Andi Offset.

Hidayat Rachmad. 2009. Maret. Jurnal Manajemen dan Kewirausahaan. Vol. 11. No. 1.

Hamdi, Asep Saepul. Metode Penelitian Kuantitatif Aplikasi dalam Pendidikan. Yogyakarta: CV Budi Utama. 2014

Jurnal Manajemen Pemasaran. 2006. April. Vol. 1. No. 1. Jurnal Humanity. 2012. Juli. Vol. 7, Nomor. 2.

Jurnal Manajemen Perhotelan. 2008. Maret. Vol. 4. No. 1. Jurnal Ekonomi dan Bisnis. 2012. Desember. Vol 11. NO. 2. Jurnal Administrasi Bisnis (JAB). 2014. Oktober. Vol. 15 No. 1.

Jurnal Humanity. ISSN: 0216-8995. Volume 7, Nomor 2. Juli 2012: 83-97. Karnaen

Perwataamadja, M. Syafi'i Antonio. 1997. Apa dan Bagaimana Bank

Islam. Yogyakarta: PT. Dana Bhakti Wakaf.

Laurens Marcella Joyce. 2004. Februari. Arsitektur dan Perilaku Manusia. Cet 1.

Jakarta: PT Grasindo.

Lupiyoadi Rambat. 2001. Manajemen Pemasaran Jasa Teori dan Praktek. Jakarta: Salemba Empat.

Muhammad. Lembaga-lembaga Keuangan Kontemporer. 2000. Yogyakarta: UII Press.

Mar'at. 1984. Sikap Manusia Perubahan Serta Pengukurannya. Ghalia Indonesia. M. Nur Rianto Al Arif. 2010. Dasar-dasar Pemasaran Bank Syariah. Bandung:

Alfabeta.

Muljono Puji, H. Djaali. 2007. Pengukuran dalam Bidang Pendidikan. Jakarta: UNJ Press. 
Malahayati. Rahasia Sukses Bisnis Rasulullah. Yogyakarta: Jogja Great

Publisher.2010.

M. Sulaiman, A. Zakaria. Jejak Bisnis Rasul. Penerjemah Gita Romadhona. Jakarta: Hikmah. 2010.

Nugroho Nasik. 2008. Trasnformasi Diri (Memberdayakan diri melalui

Hipnoterapi). Jakarta: PT Gramedia Pustaka Utama.

Nursalam. 2008. Konsep dan Penerapan Metodologi Penelitian Ilmu

Keperawatan. Ed 2. Jakarta: Salemba Medika.

Oktivinanto Oski. 2012. Tingkat Kepuasan Nasabah Bank Syariah Mandiri Cabang Salatiga Diukur Dari Dimensi Kualitas Pelayanan. Salatiga: UIN.

Philip Kotler. 1997. Manajemen Pemasaran Analisis, Perencanaan, Implementasi dan Pengendalian. Diterjemahkan Heru Jati Purwoko Wasana dari Marketing Management Analysis, Planing, Implementation and Control. Edisi ke-5. Jakarta: Erlangga.

Riduwan. 2007. Skala Pengukuran Variabel - variabel Penelitian. Bandung: Alfabeta.

Sustainability Report. 2013. PT Bank Syariah Mandiri.

Slameto. 2010. Belajar dan Faktor-Faktor yang Mempengaruhinya. Jakarta: Rineka Cipta.

Sunaryo. 2004. Psikologi Untuk Keperawatan. Cet 1. Jakarta: Buku Kedokteran ECG.

Solihah Siti Ati Almar'atus. 2011. Analisis Pengaruh Kepuasan Nasabah Terhadap Peningkatan Dana Pihak Ketiga Dan Pembiayaan yang Diberikan. Jakarta.

Sarwono Jonathan. 2010. Pintar Menulis Karangan Ilmiah. Yogyakarta: CV Andi.

TAPIS Vol. Xll1. 2013. Jan - Jun. No. 01.

Timothy A. Judge, Stephen P.Robbins. 2008. Perilaku Organisasi Organizational Behavior. Penerjemah Diana Angelica, et al., Jakarta : Salemba Empat. Buku 1. Ed 12.

Umar Husein. 2003. Metode Riset Perilaku Konsumen Jasa. Jakarta: Ghalia Indonesia.

Vertizal Riva'i. 2003. Kepemimpinan dan Perilaku Organisasi. Ed. 1. Cet 1. Jakarta : PT Raja Grafindo Persada.

Wolok Tineke. 2014. Nani Supardi. Analisis Kualitas Pelayanan Terhadap

Kepuasan Pelanggan Pada PT Bank Sinar Mas. Gorontalo. https://www.syariahmandiri.co.id/category/info-perusahaan/visi-dan-misi.

Diakses pada tanggal 8 Januari 2017. Pukul 19.54. 